\title{
"A Classic for the Elders": Marketing Charles and Mary Lamb in the Nineteenth Century
}

\section{Kate Harvey}

\section{(2) OpenEdition}

\section{Journals}

\section{Electronic version}

URL: http://journals.openedition.org/shakespeare/3717

DOI: $10.4000 /$ shakespeare.3717

ISSN: 2271-6424

\section{Publisher}

Société Française Shakespeare

\section{Electronic reference}

Kate Harvey, " "A Classic for the Elders": Marketing Charles and Mary Lamb in the Nineteenth Century ", Actes des congrès de la Société française Shakespeare [Online], 34 | 2016, Online since 10 March

2016, connection on 06 May 2019. URL : http://journals.openedition.org/shakespeare/3717 ; DOI : 10.4000/shakespeare.3717

This text was automatically generated on 6 May 2019.

(c) SFS 


\title{
"A Classic for the Elders": Marketing Charles and Mary Lamb in the Nineteenth Century
}

\author{
Kate Harvey
}

1 Charles and Mary Lamb's Tales from Shakespear (1807) has been much discussed in late twentieth- and early twenty-first-century scholarship, which has addressed for example their relationship with children's literature in the Romantic period, ${ }^{1}$ their fidelity to Shakespeare's plays and their place in the wider context of adaptations of Shakespeare. ${ }^{2}$ Critics such as Felicity James and others have also perceived in the Lambs a "desire to control and direct the reading of Shakespeare" 3 and discussed the extent to which the Tales subvert or reinforce contemporary gender and racial stereotypes. ${ }^{4}$ In this essay, rather than discussing the content of the Tales, I focus on their place in the emerging canon of "children's Shakespeare" in the century following their initial publication. This essay attempts to track the ways in which the projected audience for the Tales evolved over the course of the nineteenth century through successive repackaging and republication. It also examines how this implied audience is expected to read the Tales in relation to Shakespeare's plays and discusses the implications of the Lambs' status for current children's Shakespeares. Perry Nodelman has observed:

The actual purchasers of children's books are and always have been, overwhelmingly, not children but parents, teachers, librarians: adults. That this is the case seems part of the same cultural phenomenon that leads adults to write and publish the books to begin with-the conviction that children need things done for them by adults. In terms of success in production, what children actually want to read or do end up reading is of less significance than what adult teachers, librarians, and parents will be willing to purchase for them to read. [...] Its producers must make judgments about what to produce based not on what they believe will appeal to children but rather on what they believe adult consumers believe they know will appeal to children (or perhaps, what should appeal to them, or what they need to be taught). ${ }^{5}$

As Nodelman observes, adults, and not children, are the primary target for children's book marketing. In the case of adaptations of canonical authors for children, especially 
Shakespeare, the editions are usually promoted to adult purchasers in terms of both aspiration and nostalgia. By aspiration I mean the implication that knowledge of Shakespeare's plots and characters will grant children access to certain forms of cultural capital; by nostalgia I mean they claim to replicate for a new generation the experience of "discovering" Shakespeare's genius. Indeed, Stanley Wells refers to Tales from Shakespeare as

"a classic," rather than "a children's classic" because it is clear that the Tales (like Alice) is both read by adults and chosen by adults as a book suitable for children, not necessarily by children as a book that they are anxious to read for themselves. Indeed, its very title-unlike, say, Charlie and the Chocolate Factory or Five on a Treasure Island-requires knowledge, or information, along with cultural aspirations. $^{6}$

Whether adaptations are promoted primarily as a means to confer cultural literacy upon children or as a tool which will enable them to develop a genuine love for Shakespeare, the paratextual material that accompanies the adaptations (introductions, cover material, testimonials, etc.) is almost always addressed to adults rather than children, and almost always in a context that is outside traditional education.

When Charles and Mary Lamb wrote Tales from Shakespeare in 1807, they had a very clear vision of who their target audience was and what this audience could hope to gain from reading abridged versions of Shakespeare's plays. The opening lines of the preface plainly state, "The following Tales are meant to be submitted to the young reader as an introduction to the study of Shakespeare." The demographics of this projected young readership are refined later in the preface:

For young ladies too it has been my intention chiefly to write, because boys are generally permitted the use of their fathers' libraries at a much earlier age than girls are, they frequently having the best scenes of Shakespeare by heart, before their sisters are permitted to look into this manly book; and therefore, instead of recommending these Tales to the perusal of young gentlemen who can read them so much better in the originals, I must rather beg their kind assistance in explaining to their sisters such parts as are hardest for them to understand. ${ }^{8}$

The Lambs outline a clear progression in which young ladies first read the Lambs' retold versions of the plays, with a more knowledgeable brother helping them "to get over the difficulties;" after this they might ask this brother to read aloud "some passage which has pleased them in one of these stories, in the very words of the scene from which it is taken," and this passage "will be much better relished and understood" if they are already familiar with the story from the Lambs' version. ${ }^{9}$ Eventually, when the girls are old enough, the Tales can be safely replaced by "the true Plays of Shakespeare." 10

While the 1807 preface alludes to the particular use that "young ladies" will have for their stories, the second edition, published in 1809 , was explicitly targeted at adolescent girls. Most likely an attempt to attract new readers after the success of the first edition, the 1809 edition opens with a publisher's "Advertisement" that recommends the Tales not only as stories for "mere children," but also as "an acceptable and improving present to young ladies advancing to the state of womanhood." 11 The "Advertisement" not only targets girls specifically; it is also a clear early example of an adaptation of Shakespeare for children being advertised to adults buying gifts for young people, rather than the young people themselves. This is of course typical for juvenile literature at this time, but nevertheless the Lambs do employ direct address to an implied child reader in their 1807 preface. The preface is reproduced in the 1809 edition, but the "Advertisement" that precedes it is explicitly directed at adults looking for gift ideas. Furthermore, later editors 
of the Tales, in an attempt to recognise Mary Lamb's contribution, regularly emend the pronouns in the preface from the first person singular to third person plural and from direct address to the more neutral passive voice. For example, the last paragraph of the preface begins, "What these Tales have been to you in childhood, that and much more it is my wish that the true Plays of Shakespeare may prove to you in older years." ${ }^{12}$ In the 1995 Penguin edition of the Tales, this becomes, "What these Tales shall have been to the young readers, that and much more it is the writers' wish that the true Plays of Shakespeare may prove to them in older years." ${ }^{13}$ The effect again is an implied address to the adult caretakers of these "young readers," rather than to the readers themselves.

Prefatory material that addresses adults rather than children is a notable feature of several late nineteenth- and early twentieth-century editions of the Tales. In a special "Artist's Preface" to a 1918 edition of the Tales, illustrator Louis Rhead writes, "I know a dear lady who has for many years made it almost a duty at the holiday season to procure one or more copies of 'Lamb's Tales' for presentation to some young reader among her numerous relatives and friends," ${ }^{14}$ again a clear indication of the intended purchasers of the volume. Expensive gift editions were produced, sometimes with new illustrations specially commissioned for the purpose, which was fairly uncommon for this period, most famously those by Arthur Rackham in 1908. They also featured notes and introductions by prominent men of letters, including Charles Lamb biographer Alfred Ainger (1875), folklorist Andrew Lang (1899), and Shakespearean F.J. Furnivall (1901). These last two editions (Lang's and Furnivall's) are also noteworthy for treating the Tales not only as a gateway to "the true Plays of Shakespeare," but also as a literary "classic" in and of itself. Unlike other adaptations of Shakespeare from this period, the paratextual material in these editions of the Tales treats the Lambs, and not Shakespeare, as the primary author, providing biographical and contextual information on them alongside or instead of information about Shakespeare. Lang's edition is notable because he is among the first editors of the Tales to approach the text with anything resembling literary criticism: in his introduction he comments on Lamb's innovations in style and compares the Tales both to Charles Lamb's essays on Shakespeare and to contemporary children's literature. His introduction is addressed not only to adults who might purchase the book for a child, but also to those interested in the Tales as a piece of literary history. He claims, "To whatever extent children of to-day, an incalculable generation, may take pleasure in Lamb's Tales, they remain a classic for the elders," ${ }^{15}$ suggesting that a dual audience is envisioned for this edition. Lang even ventures the opinion that "children at the age of innocence are best introduced to Shakspeare by Shakspeare himself," 16 rather than through an intermediary like the Lambs:

It may be impertinent thus to criticise one's author. But I am arguing, as before, in the interests of children, that while they should certainly have Lamb's book placed in their hands, they should also have free access to Shakspeare himself. This I assert with the more confidence, as I doubt not that Lamb himself would have abounded in the same opinion. ${ }^{17}$

Lang offers Tales from Shakespeare as a refreshing antidote to what he sees as the "pedantries" of contemporary Shakespeare scholarship, ${ }^{18}$ joining the ranks of the numerous authors who promote their adaptations as an alternative to the less accessible Shakespeare children may have encountered in the classroom.

In the wake of the late nineteenth century British educational reforms, under which Shakespeare enjoyed pride of place on the recommended English curriculum, several new editions of the Lambs' Tales were promoted as study guides or classroom aides. Furnivall's 
is perhaps the most ambitious of these editions; Furnivall himself was of course a prolific editor of Shakespeare's plays. His edition of the Lambs therefore strongly resembles his editions of Shakespeare, complete with introductions, footnotes, and a biography of Shakespeare. He provides an extensive introduction to each of Shakespeare's comedies and tragedies, including those not adapted by the Lambs, as well as historical and biographical details for his young scholars on both Shakespeare and the Lambs. ${ }^{19} \mathrm{He}$ excludes the English history plays, but summarizes the plots of those comedies and tragedies not adapted by the Lambs. In line with contemporary scholarship, he also makes it clear which passages were not considered to have been written by Shakespeare, for example in Timon of Athens and Pericles. ${ }^{20}$ Here and elsewhere Furnivall makes a point of basing his edition on the most recent scholarship, indicating that the edition is intended to be used as a study guide for young students of Shakespeare. The tales are also rearranged, first according to genre, and then in conjectural order of composition in order to show "the growth of Shakspere's mind, and the change in the subjects which interested him and in the plots on which he founded his plays." ${ }^{21}$ The new arrangement clearly favours schoolchildren preparing for exams, as Edward Dowden's identification of the four "periods" of Shakespeare's writing career was part of the standard school curriculum at the time..$^{22}$ Furnivall's edition therefore stands in direct contrast to the stated aims of the Lambs in 1807, who assumed that their young readers would appreciate the plays primarily on the level of plot and character.

7 There is little doubt that Furnivall's edition capitalizes on both the reputation of the Lambs and the growing market for school editions of Shakespeare. However, like Lang Furnivall suggests that children are better off reading Shakespeare's plays themselves, rather than through an intermediary like Mary or Charles Lamb, particularly when it comes to the comedies:

The odd thing is, that two such humourful folk as Mary and Charles Lamb were, two who so enjoyed Shakspere's fun, made up their minds to keep all that fun (or almost all) out of his plays when they told the stories of them to boys and girls who so like fun too. [...] I can't help thinking that most boys would like the fun put into the Tales, and the stories cut shorter; but they can get it all in the plays themselves, so there's no harm done. ${ }^{23}$

This assertion, addressed to adults rather than children and loaded as it is with sweeping generalisations about children's tastes, brings up several questions, which remain unanswered. For example, we might ask, if the reader can "get it all in the plays themselves," what purpose does Furnivall's edition in fact serve? Unlike Lang, who treats the Lambs as a "classic" and an important part of literary history, Furnivall's edition purports to be an introduction to Shakespeare for the young student. However, Furnivall never explains why he has produced an edition of the Lambs rather than an edition of Shakespeare. This is especially bewildering given his determination to provide the reader with summaries of passages that the Lambs have omitted, as his assumption seems to be that an unabridged text is preferable. The reason for these contradictions within the text seems to lie in Furnivall's confused sense of his target audience. Unlike most contemporary children's Shakespeares, Furnivall's introductory material does not address readership (or indeed young people), and the edition itself is somewhat selfcontradictory in this respect. In his introduction to "Cymbeline," he informs the reader that

[t]he source of the historical legend in "Cymbeline" is Holinshed's "Chronicles," though he uses but little of it. The Iachimo story, with its artifice and intrigue, is, of course, Italian; it comes from Boccaccio's "Decameron," the ninth novel of the 
second day, the tale of Bernabo Lomellini of Genoa. The story is also in an old French romance and mystery-play, and it was afterwards in the English "Westward for Smelts" (1620), but there is no evidence that there was a translation existing earlier for Shakspere to use. ${ }^{24}$

8 When it comes to the Imogen plot, he writes that it may have come "from the Fairy-tale of Snow-white," ${ }^{25}$ and then spends two pages summarising the story of Snow White in detail so that the reader may see the parallels between the two stories. ${ }^{26}$ This indicates that he is imagining a reader who is more familiar with Boccaccio's Decameron than with "Snow White," and yet who is not ready to read Shakespeare's plays in full. This is symptomatic of the contradictions inherent in an edition like Furnivall's, in other words an annotated edition of an adaptation of a canonical text for children, promoted and marketed as a study guide for students studying the adapted text. Its underlying assumption is that retellings of Shakespeare's plays in simple narrative prose with an emphasis on the plot and characters rather than the language will assist young students struggling with the plays themselves. On the other hand, the extent of Furnivall's annotations and the assumptions he makes about his reader's existing knowledge suggests that the edition is intended for more advanced students of Shakespeare.

Tales from Shakespeare is not only a collection of adaptations of a canonical author; over the last $200+$ years it has become a canonical text in its own right. Since its publication in 1807 the names of Charles and Mary Lamb have increasingly been held up alongside that of Shakespeare as markers of cultural legitimacy. Or, more accurately, first Charles's and later Mary's name have been used in this way, since Mary's name did not appear on a title page to the Tales until 1875 even though she wrote fourteen of the twenty Tales. ${ }^{27}$ This may have been, as suggested by F.J. Furnivall in the introduction to his 1901 edition of the Lambs, "due to the publisher's belief that Charles Lamb's name would sell more copies than Mary's", ${ }^{28}$ although the reading public's knowledge of Mary's recent matricide was probably also a factor. However, in the century that followed the first publication of Tales from Shakespeare, both Charles's and Mary's names became by-words for children's Shakespeare, to the extent that many subsequent adapters of Shakespeare for young people have been compelled both to acknowledge a debt to them and to justify their own existence by explaining how their adaptation is different. In Rhead's "Artist's Preface," cited above, Rhead observes:

Since Lamb wrote these tales from the plays of Shakespeare, as he says-"especially for the young mind"-many efforts have been made by others, only to invariably produce a result inferior in every way, and so, quickly vanish from the reading world while these tales have grown in favor and esteem..$^{29}$

10 In the late nineteenth and early twentieth centuries Harrison S. Morris (1894), Arthur Quiller-Couch (1910), and Thomas Carter (1912) each published collections of retellings of the plays not adapted by the Lambs. Morris adapts all of the remaining plays, published with the Lambs' Tales over four volumes, while Quiller-Couch and Carter restrict themselves to the history plays. Each of these authors defers to the Lambs in the introduction to his edition, observing that no children's edition could hope to equal theirs and insisting that he is attempting to supplement rather than supersede the Tales. Morris is particularly self-deprecating:

While of a necessity these sixteen additional plays, here included, must come into comparison with the inimitable tales of Elia and his gifted sister, yet it has been a source of disquietude for the writer that his purpose may be misapprehended, that he may be thought to invite such a contrast, or that he deems his imperfect 
continuation as in any wise worthy of a place beside the versions made by the Lambs. ${ }^{30}$

Likewise, both Carter and Quiller-Couch acknowledge the pre-eminence of the Lambs, apologize lest they be seen as trying to imitate or surpass them, and insist that they are merely filling in the gaps by retelling those plays which the Lambs did not. Carter, after acknowledging the Tales' status as a "classic", reminds the reader that the histories "were not included in the Tales, hence there is opportunity for an endeavour to provide a prose version of this attractive section of the great plays." ${ }^{31}$ Quiller-Couch similarly asserts, "although I have taken a title very like theirs [the Lambs'], my attempt has not been to round off or tag a conclusion to their inimitable work." ${ }^{32}$

Other adapters have attempted to make a case for themselves by pointing out the flaws in the Tales or by arguing that they are no longer relevant. E. Nesbit, perhaps the second most well-known adapter of Shakespeare for children after the Lambs, acknowledges the Lambs' pre-eminence but implies that their language needs to be updated for her late Victorian readers. She writes, "Even with the recollection of Lamb's tales to help me I found it hard to tell the 'Midsummer Night's Dream' in words that these little ones could understand." ${ }^{33}$ Sidney Lee, in his introduction to the 1911 edition of Mary Macleod's Shakespeare Story-book expresses even more explicitly what he sees as the deficiencies of the Lambs' edition:

Frequently in Mary Lamb's work pertinent intricacies of plot are blurred by a silent omission of details, knowledge of which is essential to a complete understanding of the Shakespearean theme. [...] Elsewhere in the comedies, and even in Charles Lamb's own work on the tragedies, Shakespeare's text is at times misinterpreted. Consequently, however fascinating in themselves the narratives of the Lambs may prove to young readers, Lamb's Tales offer them a very fragmentary knowledge of the scope of Shakespeare's plots. ${ }^{34}$

12 Nearly 100 years later Marcia Williams, discussing her comic-style picturebooks $\mathrm{Mr}$ William Shakespeare's Tales and Bravo Mr William Shakespeare! claims the Tales "did more to put me off Shakespeare as a child than anything else." 35 She praises the Lambs as a refreshing antidote to "the moral norms of the time" but calls for their removal from modern bookshelves:

But why is it still being sold today? Is it what I should have been given to read in the mid-twentieth century? Should we expect a book, published in 1807, that is a retelling, not an original work of literature, still to talk to the twentieth-century child? [...] Does there not come a time when books such as the Lambs' Tales should take their place in academic libraries and make way for new images of Shakespeare that speak directly to the modern child? ${ }^{36}$

Williams echoes Nesbit in implying that the Lambs' Tales, though a classic in its time, does not "speak" to the readers to whom her text is addressed. However, whether praising the Tales or highlighting their shortcomings, each of these authors nevertheless uses the names of Charles and Mary Lamb to lend legitimacy to their editions, by commending the Lambs' intentions and aligning them with the adapter's own. Morris states this explicitly: the aim with which the continuation has been made is the same which inspired the first project,-a wish to provide the means for readers, old and young, to gain a knowledge of Shakspeare while from lack of time or training they are not able to find their way through the "wild poetic garden" for themselves. But coupled with this was a desire to supplement the uncompleted work of Charles and Mary Lamb, not with tales the equal of their own in grace, wisdom, or critical penetration, but with such as at least may be accepted as a help to that part of Shakspeare, and no unimportant part it is, left untouched by the original authors [my emphasis]. ${ }^{37}$ 

cited as the "original" authors, rather than Shakespeare, and alluding to their work, whether positively or negatively, suggests a noble lineage. Morris's protestations also reveal what the other authors only hint at: that as far as children's literature was concerned, by 1894 Tales from Shakespeare had supplanted Shakespeare's plays as the "original" to which all later adaptations, appropriations, and reversions are inevitably compared. Indeed, Furnivall implies that while it had been acceptable for the Lambs to alter their source material to suit their purposes, altering their adaptation is unacceptable: "Where Mary Lamb has altered Shakspere in small points [...] I have let the changes stand. The Lambs' work has become a classic, and many folk will think any addition to it an impertinence." 38 The integrity of "the Lambs' work" is here privileged above that of Shakespeare.

As noted above, the editions of Furnivall and Lang are significant because they treat Tales from Shakespeare as a work of literature to be read and studied in its own right, and not just as an aide to understanding shakespeare. With children's literature increasingly recognised as a legitimate academic discipline in the second half of the twentieth century, a new market has emerged for scholarly editions of the work, such as the 2003 Folio edition edited by Katherine Duncan-Jones and the 2007 Penguin edition, edited by Marina Warner. The overwhelming majority of new editions still target adults purchasing books for young people, promising an antidote to the more "lowbrow" fare that is perceived to make up the majority of contemporary children's literature; unlike their predecessors, these editions compete for the attention of the modern reader with Shakespeare adapted into comics, manga, computer games, flash animations, as well as high-profile films and theatrical productions aimed at young people, and with study aides like No Fear Shakespeare. These twenty-first-century editions of Tales from Shakespeare therefore rarely attempt to appeal directly to an implied child reader in their paratextual material. Instead, they target the older Shakespeare fan with illustrations of recognisable scenes from known illustrators and endorsements and prefaces from shakespeare celebrities. There is also an emphasis on the Lambs' literary status in addition to or in place of Shakespeare's. The 2007 Penguin edition, for example, attempts to strike a balance between presenting shakespeare and the Lambs as "classics", describing Tales from Shakespeare as "a captivating work of Romantic storytelling as well as an original literary homage to the Bard." ${ }^{39}$ The appeal of the Tales is here assumed to lie in their literary credentials rather than in their appeal to children, an indication that like their Victorian and Edwardian counterparts, new editions of Tales from Shakespeare are marketed as "a classic for the elders."

\section{NOTES}

1. Joseph Riehl, for example, has praised Charles Lamb for providing "an introduction to Shakespeare which would give his readers some taste of the purely literary delight which he had found in Shakespeare himself. He wished that his readers would join him in the freedom of 
literary experience, unfettered by those who would subordinate the delight of reading to logic or morality" (Joseph Riehl, Charles Lamb's Children's Literature, Salzburg, Salzburg Studies in English Literature, 1990, p. 72). In this respect Tales from Shakespear resembles other retellings of classic stories which appeared in Godwin's Juvenile Library Series, such as Charles Lamb's The Adventures of Ulysses (1808) and Lady Mountcashell's Stories of Old Daniel (1808), as well as Godwin's own Bible Stories (1802) and Fables Ancient and Modern (1805).

2. See for example Gary Taylor, Reinventing Shakespeare: A Cultural History from the Restoration to the Present, London, Vintage, 1989; Janet Bottoms, "Of Tales and Tempests", Children's Literature in Education 27.2, 1996, 73-86 and “'To Read Aright': Representations of Shakespeare for Children”, Children's Literature 32, 2004, 1-14; Howard Marchitello, "Descending Shakespeare: Toward a Theory of Adaptation for Children", in Reimagining Shakespeare for Children and Young Adults, ed. Naomi J. Miller, London, Routledge, 2003, p. 180-189.

3. Felicity James, “'Wild Tales' from Shakespeare: Readings of Charles and Mary Lamb”, Shakespeare 2.2, 2006, 152-167, p. 153.

4. See for example Jean I. Marsden, "Shakespeare for Girls: Mary Lamb and Tales from Shakespeare ”, Children's Literature 17, 1989, 47-63; Susan J. Wolfson, “Explaining to her Sisters: Mary Lamb's Tales from Shakespeare", in Women's Re-Visions of Shakespeare, ed. Marianne Novy, Urbana, University of Illinois Press, 1990, 16-40; Darlene Ciraulo, "Fairy Magic and the Female Imagination: Mary Lamb's A Midsummer Night's Dream", Philological Quarterly 78.4, 1999, 439-453; James Andreas, "Canning the Classic: Race and Ethnicity in the Lambs' Tales from Shakespeare”, in Reimagining Shakespeare for Children and Young Adults, ed. Naomi J. Miller, op. cit., p. 98-106; Erica Hateley, Shakespeare in Children's Literature: Gender and Cultural Capital, London, Routledge, 2009.

5. Perry Nodelman, The Hidden Adult: Defining Children's Literature, Baltimore, Johns Hopkins University Press, 2008, p. 4-5.

6. Stanley Wells, "Tales from Shakespeare," in British Academy Shakespeare Lectures: 1980-89, ed. E. A. J. Honigmann, Oxford, Oxford University Press, 1993, 185-212, p. 191.

7. Charles and Mary Lamb, Tales from Shakespeare, coll. Penguin Classics, London, Penguin, 2007, p. 3.

8. Ibid., p. 4.

9. Ibid.

10. Ibid., p. 5.

11. Anon., "Advertisement", in Charles [and Mary] Lamb, Tales from Shakespear, $2^{\text {nd }}$ ed., London, [T. Hodgkins], 1809, p. iii.

12. Lamb, Tales, 2007, op. cit., p. 5. This edition retains the 1809 edition's pronouns and syntax.

13. Lamb, Tales, 1995, op. cit., p. 7.

14. Louis Rhead, "Artist's Preface", in Charles [and Mary] Lamb, Tales from Shakespeare, London, Harper Brothers, 1918.

15. Andrew Lang, "Introduction", in Charles and Mary Lamb, Tales from Shakspeare, intr. Andrew Lang, illus. Robert Anning Bell, London, S. T. Freemantle, 1899, vii-xxiv, p. xxi.

16. Idem, p. ix.

17. Ibid., p. xxiii.

18. Ibid., p. xiii.

19. For example, in addition to describing the early life and later careers of the siblings, Furnivall reprints in full the account in the Morning Chronicle of "the inquest on old Mrs. Lamb" in September 1796 following Mary's infamous attack on her mother with a pair of sewing shears (F. J. Furnivall, "General Introduction", in Mary and Charles Lamb, Tales from Shakespeare, ed. F. J. Furnivall, illus. Harold Copping, London, Raphael Tuck \& Sons, 1901, vol. 1, vii-xiii, p. viin-viiin).

20. Furnivall omits Titus Andronicus, claiming that it was "only retouched by Shakspere" and that even if he had written it, it "is a story too repulsive to be told in a book for boys and girls" (Ibid., vol. 1, p. xiin). 
21. Ibid., vol. 1, p. xi-xii.

22. Edward Dowden, Shakespeare: A Critical Study of His Mind and Art, London, Henry S. King, 1875. The English Association, while discouraging teaching from highly annotated editions such as Furnivall's, also states that the teacher of Shakespeare "must map out "periods"' in Shakespeare's career (English Association, The Teaching of Shakespeare in Schools, coll. English Association Pamphlets, vol. 7, London, English Association, 1908, p. 1).

23. Furnivall, op. cit., vol. 1, p. xi.

24. Ibid., vol. 2, p. 236-237.

25. Ibid., vol. 2, p. 237.

26. Ibid., vol. 2, p. 237-238.

27. In a letter to Wordsworth dated 29 January 1807, Charles Lamb confirms that he is responsible for the adaptations of King Lear, Macbeth, Timon of Athens, Romeo and Juliet, Hamlet, and Othello, while Mary adapted the remaining fourteen Tales and wrote most of the preface (The Letters of Charles and Mary Anne Lamb, ed. Edwin W. Marrs, Jr, Ithaca, Cornell University Press, 1976, vol. 2, p. 256).

28. Furnivall, vol. 1, p. ix. By 1901, when Furnivall's edition was published, Mary Lamb's recognised status as a children's author and the higher proportion of her contribution to the Tales meant that her name was now listed first on the title page.

29. Rhead, "Artist's Preface", op. cit.

30. Harrison S. Morris, "Preface", in Charles and Mary Lamb and Harrison S. Morris, Tales from Shakespeare: With a Continuation by Harrison S. Morris, London, J. M. Dent \& Co., [1894], vol. 1, 3-5, p. 4.

31. Thomas Carter, "Preface", in Shakespeare's Stories of the English Kings, illus. Gertrude Demain Hammond, London, G. G. Harrap \& Co., 1912, v-vi, p. v. In spite of these claims, Carter had published just two years previously an edition of Shakespeare's comedies and tragedies retold for children, which featured several of the same plays as the Lambs' Tales (Thomas Carter, Stories from Shakespeare Retold, illus. Gertrude Demain Hammond, London, G. G. Harrap \& Co., 1910).

32. Arthur Quiller-Couch, "Preface", in Historical Tales from Shakespeare, 2nd ed., London, Edward Arnold, 1910, iii-vi, p. iii.

33. E. Nesbit, "Introduction", in The Children's Shakespeare, illus. Frances Brundage et al, ed. Edric Vredenburg, 2nd ed., London, Raphael Tuck \& Sons, [1897], 5-6, p. 6.

34. Sidney Lee, "Introduction", in Mary Macleod, The Shakespeare Story-book, 4th ed., London, Wells Gardner, Darton \& Co., 1911, v-xi, pp. vii-viii.

35. Marcia Williams, "Bravo, Mr. William Shakespeare!", in Reimagining Shakespeare for Children and Young Adults, ed. Naomi J. Miller, London, Routledge, 2003, 29-38, p. 31.

36. Ibid., p. 30-31. Also see Marcia Williams's article in this volume ("You Don't Mess With the Great Bard!").

37. Morris, op. cit., p. 4.

38. Furnivall, op. cit., vol. 1, p. xiii.

39. Lamb, Tales, 2007, op. cit., back cover. 


\section{ABSTRACTS}

Mary and Charles Lamb's Tales from Shakespear (1807) is generally taken as the starting point for the subgenre of "children's Shakespeare," in that it is an adaptation of Shakespeare's plays aimed at young children which promises to entertain as well as to educate its young readers. The Tales have never been out of print since 1807 and they continue to exert an influence over other authors who adapt Shakespeare for children, both in their choice of plays to adapt and in their translation of the plays from drama to prose. This essay considers the continuing legacy of the Lambs in the subgenre of children's Shakespeare by examining the ways in which the Tales were repackaged and reissued for new generations of children in the Victorian and Edwardian periods. To this end, rather than focusing on the content of the Tales themselves, this essay instead considers the paratextual elements of later editions. By examining what has been added by successive publishers in the form of prefatory material, epilogues, footnotes, and cover artwork, this essay assesses how the marketing of Shakespeare to young people has changed during this period: what strategies have authors and publishers used to sell these books, and who is their target audience? How do these authors and publishers envision the relationship between the Lambs' Tales and Shakespeare's plays? Finally, what values are evident in these continued attempts to present Shakespeare to young people through Tales from Shakespeare?

On considère généralement Tales from Shakespear (1807) de Charles et Mary Lamb comme le point d'origine du sous-genre littéraire "Shakespeare pour enfants", dans la mesure où il s'agit d'une adaptation des pièces de Shakespeare à destination d'enfants qui promet de divertir ses jeunes lecteurs tout en les instruisant. Ces Tales sont constamment rééditées depuis 1807 et elles continuent d'influencer d'autres auteurs qui adaptent Shakespeare pour un jeune public, à la fois dans la sélection des pièces et dans la traduction en prose du texte théâtral. Cet essai s'intéresse à l'héritage perpétué des Lamb dans le domaine de "Shakespeare pour enfants » en étudiant les éditions remaniées des Tales à destination de nouvelles générations d'enfants à l'époque victorienne et édouardienne. Plutôt que de se concentrer sur le contenu des Tales, on envisagera les éléments paratextuels ajoutés par les différents éditeurs des éditions plus tardives (préfaces, épilogues, notes et images de couverture) afin d'évaluer les changements dans la façon dont Shakespeare était présenté aux enfants pendant cette période : quelles stratégies de vente sont mises en œuvre par les auteurs et les éditeurs, et qui est leur public cible ? Comment conçoiventils la relation entre les Tales des Lamb et les pièces de Shakespeare? Quels valeurs transparaissent dans ces entreprises renouvelées de faire découvrir Shakespeare à un jeune public par l'intermédiaire des Tales from Shakespeare?

\section{INDEX}

Mots-clés: adaptation, compétence culturelle, Furnivall F.J., Lamb Charles, Lamb Mary, Lang Andrew, littérature d'enfance et de jeunesse, Shakespeare pour enfants

Keywords: adaptation, children's literature, children's Shakespeare, cultural literacy, Furnivall F.J., Lamb Charles, Lamb Mary, Lang Andrew 
AUTHOR

KATE HARVEY

National University of Ireland, Galway 